\title{
Multiplicity in polyp count and extracolonic manifestations in 40 Dutch patients with MYH associated polyposis coli (MAP)
}

\author{
M Nielsen, P F Franken, T H C M Reinards, M M Weiss, A Wagner, H van der Klift, S Kloosterman, \\ J J Houwing-Duistermaat, C M Aalfs, M G E M Ausems, A H J T Bröcker-Vriends, \\ E B Gomez Garcia, N Hoogerbrugge, F H Menko, R H Sijmons, S Verhoef, E J Kuipers, H Morreau, \\ M H Breuning, C M J Tops, J T Wijnen, H F A Vasen, R Fodde, F J Hes
}

J Med Genet 2005;42:e54 (http://www.jmedgenet.com/cgi/content/full/42/9/e54). doi: 10.1136/jmg.2005.033217

Objective: To investigate the contribution of MYH associated polyposis coli (MAP) among polyposis families in the Netherlands, and the prevalence of colonic and extracolonic manifestations in MAP patients.

Methods: 170 patients with polyposis coli, who previously tested negative for APC mutations, were screened by denaturing gradient gel electrophoresis and direct sequencing to identify MYH germline mutations.

Results: Homozygous and compound heterozygous MYH mutations were identified in 40 patients (24\%). No difference was found in the percentage of biallelic mutation carriers between patients with 10-99 polyps or 100-1000 polyps (29\% in both groups). Colorectal cancer was found in 26 of the 40 patients with MAP (65\%) within the age range 21 to 67 years (median 45). Complete endoscopic reports were available for 16 MAP patients and revealed five cases with gastro-duodenal polyps (31\%), one of whom also presented with a duodenal carcinoma. Breast cancer occurred in 18\% of female MAP patients, significantly more than expected from national statistics (standardised morbidity ratio $=3.75$ ). Conclusions: Polyp numbers in MAP patients were equally associated with the attenuated and classical polyposis coli phenotypes. Two thirds of the MAP patients had colorectal cancer, $95 \%$ of whom were older than 35 years, and one third of a subset of patients had upper gastrointestinal lesions. Endoscopic screening of the whole intestine should be carried out every two years for all MAP patients, starting from age 25-30 years. The frequent occurrence of additional extraintestinal manifestations, such as breast cancer among female MAP patients, should be thoroughly investigated.

$M$ AP (MYH associated polyposis) is an autosomal recessive disease characterised by the development of multiple adenomatous polyps and, eventually, colorectal cancer (CRC). ${ }^{1}$ Carriers are homozygous or compound heterozygous for germline mutations in the mutY human homologue $(M Y H)$ gene, located on chromosome 1 between $\mathrm{p} 32.1$ and $\mathrm{p} 34.3$. $^{2}$ The $M Y H$ protein is a base excision repair (BER) glycosylase that is involved in the repair of DNA damage caused by the oxidation of a guanine leading to 8-oxo-7,8-dihydroguanine (8-oxoG). ${ }^{3}$ In the process of replication it excises the adenine mispaired opposite the oxo-G. When the $M Y H$ protein is dysfunctional, $\mathrm{G}: \mathrm{C} \rightarrow \mathrm{T}: \mathrm{A}$ mutations can occur in genes such as $A P C$ and KRAS. ${ }^{14}$
Since the report by Al Tassan et al of germline biallelic $M Y H$ mutations in polyposis patients, ${ }^{1}$ several clinical studies have provided additional insight into the clinical features of MAP. $^{5-8}$ The highest percentage $(29 \%)$ of homozygous and compound heterozygous $M Y H$ mutations was found in patients with 15 to 100 adenomas..$^{5}$ In two series-with, respectively, 107 and 38 patients with classical FAP but without the APC mutation-biallelic $M Y H$ mutations were identified in $7 \%$ and $13 \%$ of the cases. ${ }^{58}$ Accordingly, the majority of MAP cases were characterised by polyp counts in the range from 10 to 100 . So far, six "CRC only" patients and one with more than 1000 polyps who carry biallelic $M Y H$ mutations have been described..$^{9-11}$

Approximately $50 \%$ of the MAP patients develop CRC. ${ }^{5} 810$ A few extracolonic manifestations-including duodenal adenomas $(n=3)$, osteoma $(n=2)$, congenital hypertrophy of the retinal pigment epithelium (CHRPE) $(n=4)$, and dental cysts $(\mathrm{n}=1)^{578}$-have been observed in MAP patients. In addition, one case of stomach cancer was reported in a 17 year old patient.

It is likely that other reports focused mainly on the occurrence of colonic lesions. In this study we investigated the contribution of MAP among polyposis families in the Netherlands, and the prevalence of both colonic and extracolonic manifestations in MAP patients.

\section{METHODS}

We selected 170 index patients from all the patients with polyps referred for APC germline mutation analysis to the DNA Diagnostic Laboratory of Human and Clinical Genetics in Leiden from 1986 to 2002. Patients were recruited from throughout the Netherlands, the vast majority being of white northern European origin. We excluded those with a pathogenic $A P C$ or mismatch repair gene germline mutations, inadequate clinical data, or insufficient DNA quality for $M Y H$ mutation analysis. We did not exclude two patients with the low penetrant $11307 \mathrm{~K}$ mutation in the APC gene. ${ }^{12}$ Informed consent was obtained for DNA testing according to protocols approved by local ethics review boards. Clinical and pathological data were obtained from patient records to confirm the diagnosis. The endoscopic reports were studied to assay the total number of polyps in the colon that the patient had developed over time (metachronous count). For practical

Abbreviations: AFAP, attenuated familial adenomatous polyposis; $A P C$, adenomatous polyposis coli; BER, base excision repair; $C H R P E$, congenital hypertrophy of the retinal pigment epithelium; CRC, colorectal cancer; DGGE, denaturing gradient gel electrophoresis; FAP, familial adenomatous polyposis coli; MAP, MYH associated polyposis; MSI, microsatellite instability; SMR, standardised morbidity ratio 
Table 1 Primer sets for MYH gene mutation analysis

\begin{tabular}{|c|c|c|}
\hline Exon & Purpose & Oligonucleotide sequence $\left(5^{\prime}-3^{\prime}\right)$ \\
\hline 1 & Sequence & $\begin{array}{l}\text { cggtgtacaacggaacttgt } \\
\text { gacgtctgaacggaagttcg }\end{array}$ \\
\hline 2 & Sequence & $\begin{array}{l}\text { ccttggaaggectcaaaat } \\
\text { cctgaatctgectttcatgg }\end{array}$ \\
\hline 2 & DGGE & 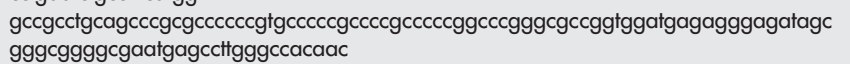 \\
\hline $3-4-5$ & Sequence & $\begin{array}{l}\text { atactgecacaggctgct } \\
\text { ctctcatctggggtctga }\end{array}$ \\
\hline $6-7-8$ & Sequence & $\begin{array}{l}\text { ttggggtgggtgtagagaag } \\
\text { agaggggccaaagagttagc }\end{array}$ \\
\hline 7 & DGGE & 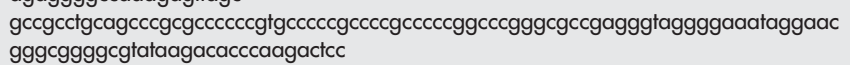 \\
\hline 8 & DGGE & 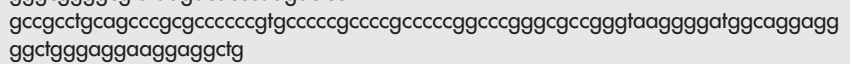 \\
\hline $9-10-11$ & Sequence & $\begin{array}{l}\text { gtgcccagcctccttcct } \\
\text { agaactggaatggggcttct }\end{array}$ \\
\hline 10 & DGGE & 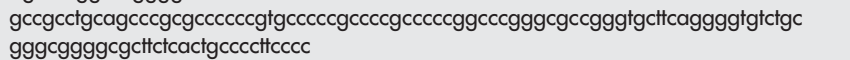 \\
\hline $12-13$ & Sequence & $\begin{array}{l}\text { tctaggttggeccctaaagc } \\
\text { aagggtcaaggggttcaaat }\end{array}$ \\
\hline 14 & Sequence & $\begin{array}{l}\text { cggaatagccaaggatgitg } \\
\text { ttcatgtagaacatgtaggaaacac }\end{array}$ \\
\hline 15 & Sequence & $\begin{array}{l}\text { tgaagttaagggcagaacacc } \\
\text { actgatggetccacaattca }\end{array}$ \\
\hline 16 & Sequence & $\begin{array}{l}\text { gggaaagggagagaggacaa } \\
\text { caaaaataagcacttactaacaacag }\end{array}$ \\
\hline
\end{tabular}

reasons, the index patients were divided into four categories: less than 10 adenomas; between 10 and 100 adenomas; between 100 and 1000 adenomas; and more than 1000 adenomas. Unfortunately, the endoscopy and pathology reports for 29 index patients gave descriptions like "polyposis" or "multiple" rather than the exact number of adenomas.

\section{MYH mutation analysis}

Polymerase chain reaction and denaturing gradient gel electrophoresis

All DNA amplifications were carried out in a $25 \mu \mathrm{l}$ volume containing $45 \mathrm{mM}$ Tris $\mathrm{HCl}, \mathrm{pH} 8.3,11 \mathrm{mM}\left(\mathrm{NH}_{4}\right)_{2} \mathrm{SO}_{4}$, $45 \mathrm{mM} \mathrm{MgCl}_{2}, 0.2 \mathrm{mM}$ of each dNTP, $110 \mu \mathrm{g} / \mathrm{ml}$ bovine serum albumin (BSA), $4 \mu \mathrm{M}$ EDTA, $10 \%$ glycerol, 10 pmol of each primer, and $1 \mathrm{U}$ polymerase and were subjected to 35 polymerase chain reaction (PCR) cycles ( 30 seconds at $94^{\circ} \mathrm{C}$, 30 seconds at $55^{\circ} \mathrm{C}$ or $58^{\circ} \mathrm{C}$, and 60 seconds at $72^{\circ} \mathrm{C}$ ). Oligonucleotide sequences (table 1) were designed from intron-exon boundaries of the MYH gene using the DNA20 computer program (designed by HT Huisman, University of Groningen). For exons 2, 7, 8, and 10, DGGE analysis was undertaken and a 55 base pair (bp) GC clamp was present at the $5^{\prime}$ of the forward oligonucleotide. Denaturing gradient gel electrophoresis (DGGE) analysis was carried out as described by Fodde et al. ${ }^{13}$

\section{Direct sequence analysis}

The PCR for the sequence analysis was carried out with oligonucleotide primers specific for the 16 coding exons of the MYH gene, extended with an M13 forward or reverse sequence. Some exons were combined into one fragment (table 1), and in all nine fragments covered the 16 coding exons of the MYH gene. The primer sequences are given in table 1. PCR products were sequenced on an ABI 3730 DNA analyser (Applied Biosystems, Foster City, California, USA) using their BigDye Terminator cycle sequencing ready reaction kit. The raw sequence data were analysed using SeqScape software for comparative sequence analysis (Applied Biosystems). Detected mutations were confirmed on a second, independent DNA sample when available.

Nucleotide numbering of the MYH gene was based on the sequence of the NCBI website (http://www.ncbi.nlm.nih.gov/, accession number NT_004852.14), changed according to published reports, ${ }^{1}$ with base 1 corresponding to the first base of the initiation codon, and the first 11 codons of exon 3 considered as non-coding). Splice prediction was carried out with Fruitfly and SpliceSiteFinder software, available from

Table 2 Results of MYH mutation analysis in relation to cumulative polyp counts among 170 patients (metachronous)

\begin{tabular}{lllll}
\hline $\begin{array}{l}\text { Number of } \\
\text { polyps }\end{array}$ & $\begin{array}{l}\text { Number of } \\
\text { patients }\end{array}$ & $\begin{array}{l}\text { Biallelic } \\
\text { carriers }\end{array}$ & $\begin{array}{l}\text { Monoallelic } \\
\text { carriers }\end{array}$ & $\begin{array}{l}\text { Age at diagnosis } \\
\text { (mean), years }\end{array}$ \\
\hline $1-9$ & 33 & 0 & $1(1 \mathrm{UV})$ & $22-73(47)$ \\
$10-99$ & 83 & $24(29 \%)$ & $3(1 \mathrm{UV})$ & $12-76(46)$ \\
$100-1000$ & 24 & $7(29 \%)$ & 1 & $12-67(41)$ \\
$>1000$ & 1 & 0 & 0 & 48 \\
Polyposis & 17 & $7(41 \%)$ & 0 & $21-59(41)$ \\
Multiple & 10 & $2(20 \%)$ & 1 & $16-64(46)$ \\
Unknown & 2 & 0 & 0 & $12-76(45)$ \\
Total & 170 & $40(24 \%)$ & $6(2$ UV) $(3.5 \%)$ & \\
\hline *Number of polyps not defined. & & & \\
UV, unclassified variant. &
\end{tabular}




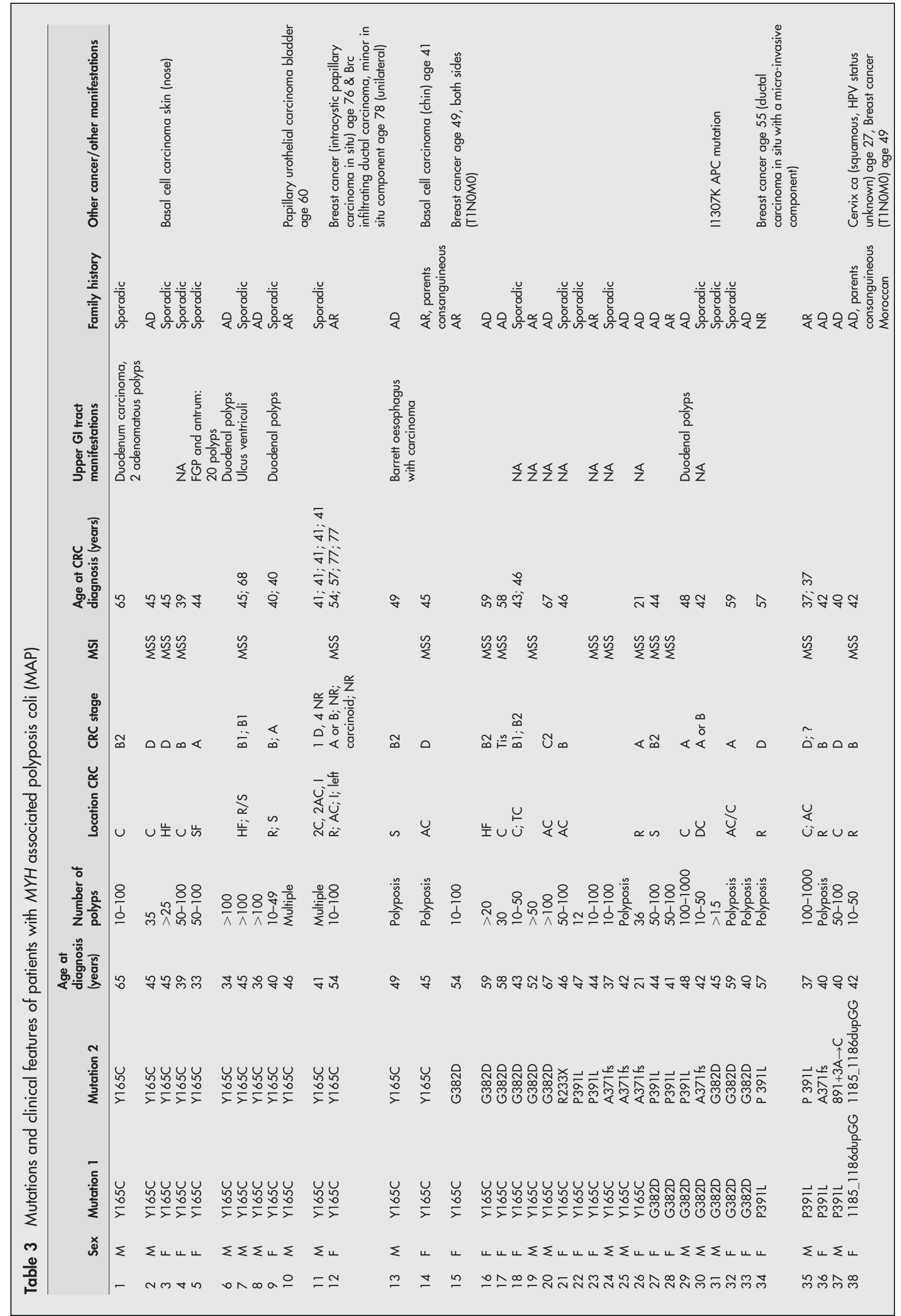




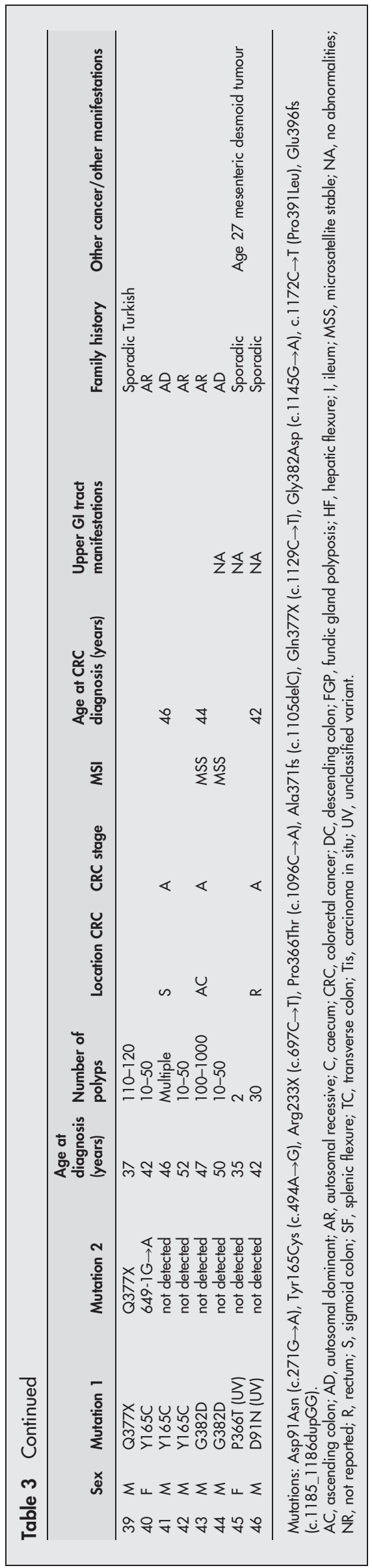

the internet: http://www.fruitfly.org/seq_tools/splice.html, http://www.genet.sickkids.on.ca/ ali/splicesitefinder.html.

Southern blot analysis of MYH was carried out for 95 of the 170 index patients and was done mainly as previously described. ${ }^{14}$ We used HindIII and BglII digests, followed by hybridisation with two cDNA probes encompassing exons 110 (MYH 5') and exons 10-16 (MYH 3'), respectively.

\section{Statistics}

Differences in percentages were assessed by the $\chi^{2}$ test. The $\mathrm{F}$ test was used for comparing age of diagnosis and percentages in more than two groups. A probability (p) value of $<0.05$ was considered as statistically significant. All tests were carried out with SPSS 11.01 (SPSS, Chicago, Illinois, USA). We calculated the expected number of breast cancer cases using rates for each five year calendar period and age group from the Dutch Cancer Registry. ${ }^{15}$ SMR-exact was used to calculate the significance and (Poisson) confidence interval for the standardised morbidity ratio (SMR) - that is, the ratio between observed and predicted morbidity of breast cancer among the female MYH patients compared with breast cancer in the Dutch population (http://home.clara.net/sisa/ smrhlp.htm).

\section{RESULTS}

\section{MYH mutation analysis}

Of the 170 index patients analysed, 40 (24\%) were found to carry (presumed) homozygous or compound heterozygous MYH germline mutations (table 2). In addition, we identified six carriers of a heterozygous mutation $(3.5 \%)$ - four pathogenic mutations and two unclassified variants. Two index patients with biallelic $M Y H$ mutations had consanguineous parents (table 3). Southern blot analysis in 95 patients did not reveal any gross genomic rearrangements of the $M Y H$ gene. One novel missense change, P391L, was found in 14\% of the patients with biallelic mutations. Two other novel nonsense mutations, Q377X and R233X, were found: the first in a homozygous patient of Turkish origin, and the second in a patient who was compound heterozygote for R233X and Y165C. We also identified one novel, c649-1G $\rightarrow$ A (IVS8) and one previously reported splice site mutation, $c 891+3 \mathrm{~A} \rightarrow \mathrm{C}$ (IVS10), affecting the wild type splice acceptor and splice donor recognition sites of exons 8 and 10, respectively. Two further unclassified variants were found in patients where no additional $M Y H$ variant could be identified: D91N in exon 3, and P366T in exon 13, within a stretch of evolutionarily conserved and non-conserved residues, respectively. The pathogenicity of both substitutions is unclear from the evidence available.

\section{Colorectal polyp multiplicity and cancer risk in MAP}

Equal frequencies of biallelic $M Y H$ germline mutations were observed in patients with 10-99 (29\%) and 100-1000 adenomas (29\%) (table 2). No biallelic mutations were found in patients with 1-9 polyps or in a patient with more than 1000 polyps.

The mean age at diagnosis of MAP patients was 45 years, ranging between 21 and 67 (median, 45). In most MAP patients, the adenomatous polyps were distributed throughout the colon.

Of the 40 patients with homozygous or compound heterozygous MYH mutations, 26 (65\%) were diagnosed with CRC, in 130 patients without biallelic MYH mutations the percentage of CRC patients was 45\% (59/130). In MAP patientsx CRC was found at first endoscopy in a majority of cases ( 24 of 26). Sixteen of the 26 CRC cases (62\%) were right sided (that is, proximal to the splenic flexure). Two patients presented with two and one patient with five synchronous carcinomas (patients 9, 35, and 11, respectively). A second 


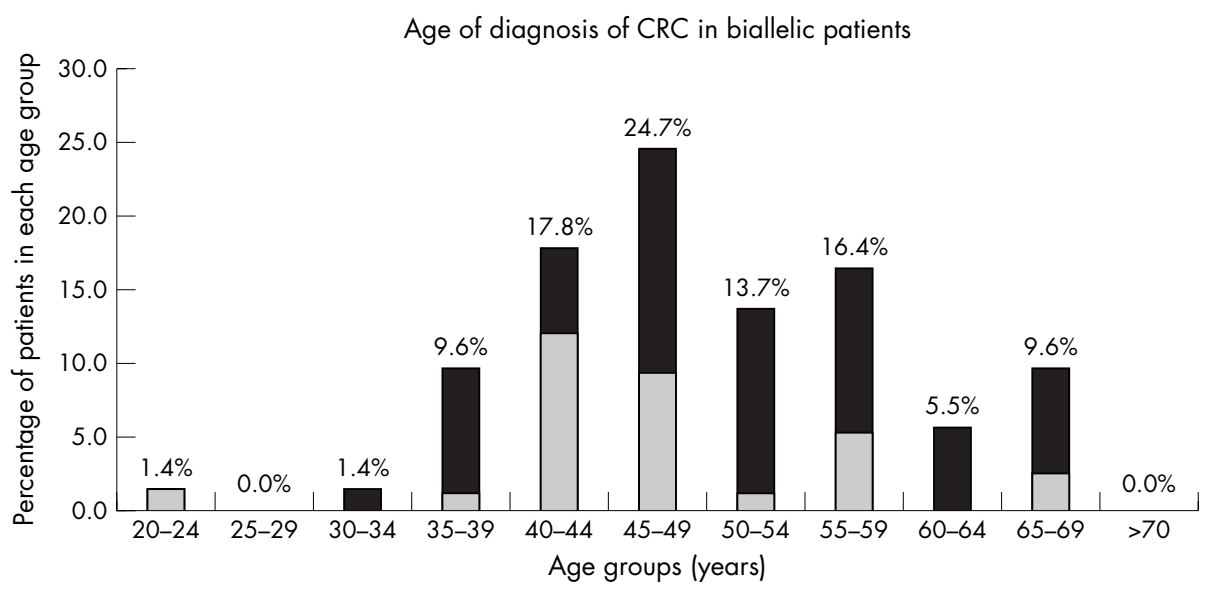

Figure 1 Age at diagnosis of homozygous and compound heterozygous MAP patients with colorectal carcinoma (CRC). In all, 73 patients are included, 26 from our series (light bars) and 47 (dark bars) from other studies. $5,7-9,24,25$ (metachronous) CRC was identified during follow up in two other patients, while a third patient developed three adenocarcinomas in the colon and a carcinoid tumour in the ileum metachronously (patients 7,18 , and 12, respectively, table 3 ). In all, 37 CRCs were found in 26 patients. The Dukes classification was variable: seven of the 26 cases were stage D ( $27 \%$ ), five of which were right sided. Microsatellite instability (MSI) was analysed in CRCs from 16 index patients and all the 16 tumours tested showed stable microsatellites. The median age of onset of CRC in our series is 45 years, ranging from 21 to 67. Figure 1 shows the distribution of age of onset of CRC in MAP patients both in our series and those in published reports.

Thirty six patients with biallelic $M Y H$ gene mutations underwent bowel surgery at a mean age of 46 years (ranging from 21 to 67 years): 12 because of their high polyp counts, and 24 because of the presence of colorectal carcinoma. Thirty two patients underwent a total colectomy, carried out in one or more surgical procedures.

\section{Extracolonic manifestations in MAP}

Of 16 MAP patients who underwent upper gastrointestinal endoscopy, five $(31 \%)$ showed an FAP associated extracolonic manifestation, namely duodenal adenomas in four cases and gastric fundic gland polyposis in one. Duodenal carcinoma was diagnosed in one of the four patients with duodenal adenomas. The duodenal adenomas were diagnosed at a mean age of 52 years (range 36 to 65). One patient was reported to have oesophageal cancer in the presence of a Barrett's oesophagus with dysplasia.
Of the 22 female MAP patients, four (18\%) have been diagnosed with breast cancer. The first patient had a unilateral breast cancer twice, though with different histologies, diagnosed at age 76 and 78 years old (intracystic papillary carcinoma in situ and an infiltrating ductal carcinoma with a minor in situ component; patient 12). The second patient was diagnosed with breast cancer at age 55 years (ductal carcinoma in situ with a microinvasive component; patient 34). The third patient had bilateral breast cancer at age 49 years (pathology unknown; patient 15), and the fourth patient had breast cancer at age 49 years (pathology unknown; patient 38) but had also had cervical carcinoma at age 27 years (squamous cell carcinoma, human papillomavirus (HPV) status unknown).

\section{Family history}

Family history data were available for 167 of the index patients. In all, 103 index patients had a family history compatible with an autosomal dominant pattern of inheritance (that is, more than one generation with either polyposis or $\mathrm{CRC}$ ), whereas 64 cases suggest recessive inheritance. The frequency of biallelic MYH mutations in these two groups is shown in table 4 . We were able to obtain family history data for 39 of the 40 patients with biallelic MYH mutations, and we identified a total of 164 siblings and 78 parents. Of 92 siblings examined, 29 (32\%) were found to have polyps or colorectal carcinomas. Of 78 parents, five were diagnosed with CRC, four with polyps, while endoscopies revealed no abnormalities in six parents.

Table 4 Results of MYH mutation analysis in relation to family history of polyposis patients

\begin{tabular}{|c|c|c|c|c|}
\hline \multirow[b]{2}{*}{ Number of polyps } & \multicolumn{2}{|c|}{ Sporadic or autosomal recessive* } & \multicolumn{2}{|c|}{ Autosomal dominant } \\
\hline & Total & Biallelic & Total & Biallelic \\
\hline $1-9$ & 5 & None & 27 & None \\
\hline $10-99$ & 37 & $17(46 \%)$ & 45 & $7(16 \%)$ \\
\hline $100-1000$ & 10 & $3(30 \%)$ & 14 & $4(29 \%)$ \\
\hline$>1000$ & 1 & None & None & None \\
\hline Polyposis & 3 & $2(67 \%)$ & 13 & $4(31 \%)$ \\
\hline Multiple & 7 & $2(29 \%)$ & 3 & None \\
\hline Unknown & 1 & None & 1 & None \\
\hline Total & 64 & $24(38 \%)$ & 103 & $15(15 \%)$ \\
\hline
\end{tabular}

For assessing the mode of inheritance, first and second degree relatives were considered as patients if they had $\geqslant 3$ adenomas (or 2 at young age, ie, $<40$ years) and/or CRC. The family history was considered dominant if patients occurred in at least two generations, and recessive if patients were siblings. The family history for three index patients was not available and these three were not included in this table.

*26 patients with a recessive pattern of inheritance and 38 apparently sporadic cases with 9 and 15 biallelic MYH patients, respectively. 


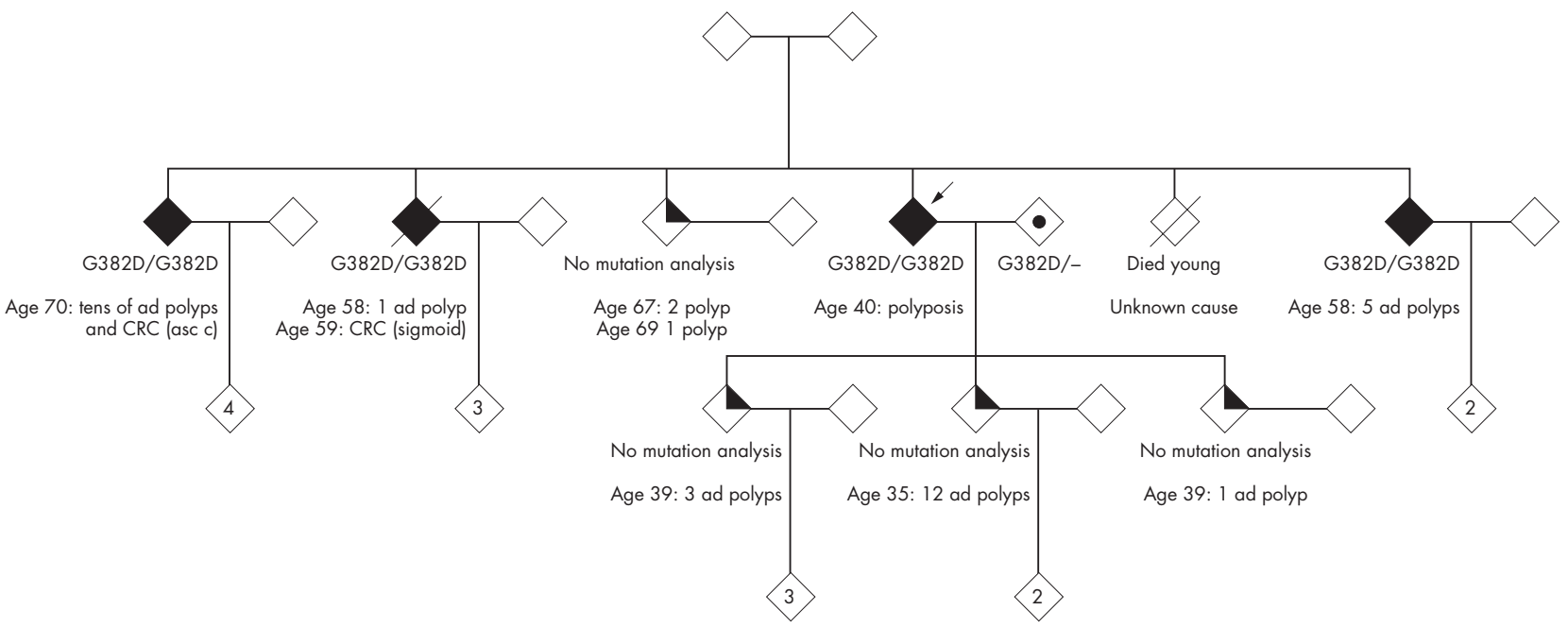

Figure 2 Pseudodominant inheritance pattern in an MAP (MYH associated polyposis coli) pedigree (patient 33). ad, adenomatous; asc, ascending colon; CRC, colorectal carcinoma.

\section{DISCUSSION}

In this study we describe the largest series of patients with homozygous and compound heterozygous mutations in the MYH gene reported so far. We found that in the Dutch population, MAP polyp counts are equally associated with the attenuated and florid forms of polyposis coli. This is in sharp contrast with previous studies in which the yield of the biallelic $M Y H$ mutation carriers was higher in patients with 10-100 polyps than in those with 100-1000 polyps. $^{58}$ As in these and other studies, we investigated patients who previously tested negative for the presence of germline $A P C$ mutations. Hence we assume that the actual prevalence of $M Y H$ biallelic mutations among polyposis patients is lower. Considering that $A P C$ mutations are detected in approximately $60-80 \%$ of classical FAP patients and in $10-30 \%$ of attenuated FAP patients, $M Y H$ mutations are likely to account for about $10 \%$ and $20-25 \%$ of patients in these groups, respectively. ${ }^{16} 17$

\section{MYH mutation spectrum}

DGGE and direct sequencing identified 40 biallelic germline MYH gene point mutations in 170 index patients. Apparently, larger genomic rearrangements do not play an important role in MAP as Southern blot analysis in a subset of patients did not reveal any deletions or duplications.

In our series we found a relatively high frequency (14\%) of a previously unreported mutation, P391L in exon 13, which may suggest a founder mutation. Although haplotype analysis was not carried out, P391L carriers were found in different regions of the central and southern parts of the Netherlands and are apparently unrelated. Population specific $M Y H$ mutations have already been reported in India $(\mathrm{E} 466 \mathrm{X})^{7}$ and Italy (c1395_1396delGGA). ${ }^{8}$

\section{MAP colonic manifestations}

CRC was found in $65 \%$ of biallelic $M Y H$ mutation carriers. The mean age of onset was 47 years. One case (patient 26) presented with CRC at age 21 and is the youngest MAP patient with CRC reported so far. Figure 2 shows that the vast majority of MAP patients (95\%) develop CRC after the age of 35 years. In contrast with the findings of Lipton et al, who reported $71 \%(17 / 24)$ of the carcinomas being confined to the left side of the colon, ${ }^{4}$ we found CRC in our MAP patients was predominantly right sided $(62 \%)$. The percentage of Dukes stage D colorectal cancers found in MAP patients $(27 \%)$ is higher than the percentage found in general Dutch CRC patients $(19 \%){ }^{18}$ The latter observation can partly be explained by the fact that five of these CRC patients had not been recognised with polyposis before, and their CRCs were right sided, which may explain their late symptoms.

\section{Extracolonic manifestations}

We found a relatively high percentage (31\%) of upper gastrointestinal tract manifestations in MAP patients who underwent endoscopy (15). One patient (No l) was found to have a duodenal carcinoma. To date, clinical data of approximately 100 MAP patients have been described and only three cases of duodenal adenomas without duodenal carcinoma have been reported. ${ }^{57}$ Unfortunately, the number of MAP patients who underwent upper gastrointestinal screening was not reported. As endoscopy of the upper tract is not routinely carried out in patients with 10-100 polyps, $3 \%$ is most likely to represent an underestimation. Among FAP patients, the cumulative incidence of duodenal adenomas is $90 \%$ and $4.5 \%$ developed duodenal carcinomas. ${ }^{19}$ In attenuated FAP, duodenal adenomas are seen often and duodenal cancer has been described in a few cases. $^{20}$

The percentage of cases of breast cancer found in female MAP patients was $18 \%(4 / 22)$, of whom two had double breast cancer (bilateral and unilateral). The SMR for developing breast cancer for female MAP patients compared with the Dutch population is significantly higher than 1 (3.75, 95\% confidence interval, 1.02 to 9.57; $\mathrm{p}=0.019$ ). Unfortunately, the prevalence of double tumours in the Dutch population is unknown and this factor could not therefore be included in the calculation. To exclude the possibility that polyposis patients develop breast cancer for other reasons, we also calculated the SMR in female polyposis patients without MYH mutations $(\mathrm{n}=48)$. A nonsignificant SMR of 0.88 was found (95\% confidence interval, 0.11 to $3.16 ; \mathrm{p}=0.4$ ). It is noteworthy that the BRCAl and BRCA2 tumour suppressor proteins, loss of function of which predisposes to breast or ovarian cancer, participate in the base excision repair of 8-oxo-G lesions. ${ }^{21}$ Accordingly, loss of BER function owing to biallelic MYH mutations may underlie the increased breast cancer risk observed among Dutch MAP patients. Moreover, $M Y H$ knock-out mice that also carry heterozygous APC mutations are more prone to develop mammary tumours than $A p c$-heterozygotes only. ${ }^{22}$ 


\section{MAP family history}

As expected, more MAP patients were identified in cases with a family history compatible with an autosomal recessive mode of inheritance or apparently sporadic presentation (i.e. $24 / 64,38 \%)$ than in dominant cases $(15 / 103,15 \%)$ $(\mathrm{p}=0.001)$ (table 4). Given an estimated frequency of heterozygotes in the population of $1-2 \%,{ }^{1}{ }^{10}$ pseudodominant inheritance of MAP is not uncommon, as illustrated in patient 33's pedigree (fig 2). Polyps or CRC were found in $32 \%$ of the siblings screened, which is again in agreement with an autosomal recessive mode of transmission.

\section{Genotype-phenotype correlations}

In $E$ coli it has been found that the corresponding mutation of Y165C (Y82D) has a more deleterious effect on the rate of adenine removal than the corresponding mutation of G382D (G253D). ${ }^{1}$ In addition, heterozygous Y165C mutation carriers are associated with a higher risk for CRC than G382D heterozygotes. ${ }^{9}$ In this study, we detected a non-significantly earlier age of onset of colorectal polyps in patients homozygous for MYH Y165C compared with G382D and all other biallelic carriers (data not shown). Combining our data with 93 MAP patients reported worldwide, age at diagnosis of homozygous Y165C mutation carriers was on average five years earlier than all other biallelic mutation carriers $(\mathrm{p}=0.011 ; 95 \%$ confidence interval, 1.1 to 8.8$) .{ }^{578101123}$ However, there was no significant difference in age of onset between homozygotes for Y165C and G382D. We found no other significant differences among the three groups relative to polyp multiplicities or CRC risk.

\section{Conclusions}

We show that patients with a polyp count compatible with either the classical or attenuated form of polyposis coli should be screened for the presence of $M Y H$ mutations. As the vast majority of MAP patients presents with CRC from the age of 35 years and there is a relatively high prevalence of lesions of the upper gastrointestinal tract, we recommend endoscopic screening of the lower and upper gastrointestinal tracts every two years for MAP patients from 25 to 30 years of age. Limited numbers of colonic adenomas may initially be treated by polypectomy, but in patients with large numbers of polyps a subtotal colectomy is indicated. The relatively high prevalence of breast cancer warrants further exploration of the involvement of $M Y H$ in breast cancer.

\section{ACKNOWLEDGEMENTS}

We thank the following clinicians for providing information: $J$ van Aken (Gelderse Vallei Hospital, Ede); PWE Haeck (Refaja Hospital, Stadskanaal); GJPM Jonkers (Rijnland Hospital); G Griffioen (LUMC); FA Lall Mohamed (Slingeland Hospital, Doetinchem); OJL Loosveld (Amphia Hospital, Breda); EJ Spillenaar Bilgen (Rijnstate Hospital, Arnhem). We also thank JMC Junggeburt and R Zwaan (LUMC) and M Veldhuizen (The Netherlands Foundation for the Detection of Hereditary Tumours) for database management, and M Gerritsen (The Netherlands Foundation for the Detection of Hereditary Tumours) for assistance with collecting data.

\footnotetext{
Authors' affiliations

M Nielsen, T H C M Reinards, M M Weiss, $H$ van der Klift, S Kloosterman, M H Breuning, C M J Tops, J T Wijnen, F J Hes, Centre of Human and Clinical Genetics, Leiden University Medical Centre, Leiden, Netherlands

P F Franken, R Fodde, Department of Pathology, Josephine Nefkens Institute, Erasmus University Medical Centre, Rotterdam, Netherlands A Wagner, Department of Clinical Genetics, Erasmus University Medical Centre, Rotterdam

J J Houwing-Duistermaat, Department of Medical Statistics and Bioinformatics, Leiden University Medical Centre

C M Aalfs, Department of Clinical Genetics, Academic Medical Centre, Amsterdam, Netherlands
}

M G E M Ausems, Department of Medical Genetics, University Medical Centre, Utrecht, Netherlands

E B Gomez Garcia, Department of Clinical Genetics, University Hospital, Maastricht, Netherlands

N Hoogerbrugge, Department of Human Genetics and Hereditary Cancer Clinic, University Medical Centre, Nijmegen, Netherlands

F H Menko, Department of Clinical Genetics and Human Genetics, VU University Medical Centre, Amsterdam

R H Sijmons, Department of Clinical Genetics, University Medical Centre, Groningen, Netherlands

S Verhoef, Family Cancer Clinic, Netherlands Cancer Institute, Amsterdam

E J Kuipers, Department of Gastroenterology and Hepatology, Erasmus University Medical Centre, Rotterdam

H Morreau, Department of Pathology, Leiden University Medical Centre, Leiden

H F A Vasen, The Netherlands Foundation for the Detection of Hereditary Tumours, Leiden

Competing interests: none declared

Correspondence to: DrF J Hes, Centre for Human and Clinical Genetics, LUMC, PO Box 9600, 2300 RC Leiden, Netherlands; F.J.Hes@lumc.nl

Revised version received 29 April 2005

Accepted for publication 4 May 2005

\section{REFERENCES}

1 Al Tassan N, Chmiel NH, Maynard J, Fleming N, Livingston AL, Williams GT, Hodges AK, Davies DR, David SS, Sampson JR, Cheadle JP. Inherited variants of MYH associated with somatic $\mathrm{G}: \mathrm{C} \rightarrow \mathrm{T}: \mathrm{A}$ mutations in colorectal tumors. Nat Genet 2002;30:227-32.

2 Slupska MM, Baikalov C, Luther WM, Chiang JH, Wei YF, Miller JH. Cloning and sequencing a human homolog (hMYH) of the Escherichia coli mutY gene whose function is required for the repair of oxidative DNA damage. J Bacteriol 1996; 178:3885-92.

3 Michaels ML, Miller JH. The GO system protects organisms from the mutagenic effect of the spontaneous lesion 8-hydroxyguanine (7,8-dihydro-8oxoguanine). J Bacteriol 1992;174:6321-25.

4 Lipton L, Halford SE, Johnson V, Novelli MR, Jones A, Cummings C, Barclay E, Sieber O, Sadat A, Bisgaard ML, Hodgson SV, Aaltonen LA, Thomas HJ, Tomlinson IP. Carcinogenesis in MYH-associated polyposis follows a distinct genetic pathway. Cancer Res 2003:63:7595-9.

5 Sieber OM, Lipton L, Crabtree M, Heinimann K, Fidalgo P, Phillips RK, Bisgaard ML, Orntoft TF, Aaltonen LA, Hodgson SV, Thomas HJ, Tomlinson IP. Multiple colorectal adenomas, classic adenomatous polyposis, and germ-line mutations in MYH. N Engl J Med 2003;348:791-9.

6 Jones S, Emmerson P, Maynard J, Best JM, Jordan S, Williams GT, Sampson JR, Cheadle JP. Biallelic germline mutations in MYH predispose to multiple colorectal adenoma and somatic $\mathrm{G}: \mathrm{C} \rightarrow \mathrm{T}: \mathrm{A}$ mutations. Hum Mol Genet 2002;11:2961-7.

7 Sampson JR, Dolwani S, Jones S, Eccles D, Ellis A, Evans DG, Frayling I, Jordan S, Maher ER, Mak T, Maynard J, Pigatto F, Shaw J, Cheadle JP. Autosomal recessive colorectal adenomatous polyposis due to inherited mutations of MYH. Lancet 2003;362:39-41.

8 Gismondi V, Meta M, Bonelli L, Radice P, Sala P, Bertario L, Viel A, Fornasarig M, Arrigoni A, Gentile M, Ponz DL, Anselmi L, Mareni C, Bruzzi P, Varesco L. Prevalence of the Y165C, G382D and 1395delGGA germline mutations of the MYH gene in Italian patients with adenomatous polyposis coli and colorectal adenomas. Int J Cancer 2004;109:680-4.

9 Croitoru ME, Cleary SP, Di Nicola N, Manno M, Selander T, Aronson M, Redston M, Cotterchio M, Knight J, Gryfe R, Gallinger S. Association between biallelic and monoallelic germline MYH gene mutations and colorectal cancer risk. J Natl Cancer Inst 2004;96:1631-4.

10 Wang L, Baudhuin LM, Boardman LA, Steenblock KJ, Petersen GM, Halling KC, French AJ, Johnson RA, Burgart U, Rabe K, Lindor NM, Thibodeau SN. MYH mutations in patients with attenuated and classic polyposis and with young-onset colorectal cancer without polyps. Gastroenterology 2004;127:9-16.

11 Isidro G, Laranjeira F, Pires A, Leite J, Regateiro F, Castro ESousa, Soares J, Castro C, Giria J, Brito MJ, Medeira A, Teixeira R, Morna H, Gaspar I, Marinho C, Jorge R, Brehm A, Ramos JS, Boavida MG. Germline MUTYH (MYH) mutations in Portuguese individuals with multiple colorectal adenomas. Hum Mutat 2004;24:353-4.

12 Woodage T, King SM, Wacholder S, Hartge P, Struewing JP, McAdams M, Laken SJ, Tucker MA, Brody LC. The APCI1307K allele and cancer risk in a community-based study of Ashkenazi Jews. Nat Genet 1998;20:62-5.

13 Fodde R, van der LR, Wijnen J, Tops C, van der KH, Leeuwen-Cornelisse I, Griffioen $G$, Vasen $H$, Khan PM. Eight novel inactivating germ line mutations at the APC gene identified by denaturing gradient gel electrophoresis. Genomics 1992;13:1162-8.

14 Wijnen J, van der KH, Vasen H, Khan PM, Menko F, Tops C, Meijers HH, Lindhout $D$, Moller P, Fodde R. MSH2 genomic deletions are a frequent cause of HNPCC. Nat Genet 1998;20:326-8. 
15 In: Visser O, Siesling S, van Dijck JAAM, eds. Incidence of cancer in the Netherlands 1999/2000. Utrecht: Vereniging van Integrale kankercentra, 2003.

16 Powell SM, Petersen GM, Krush AJ, Booker S, Jen J, Giardiello FM, Hamilton SR, Vogelstein B, Kinzler KW. Molecular diagnosis of familia adenomatous polyposis. N Engl J Med 1993;329:1982-7.

17 van der Luijt RB, Khan PM, Vasen HF, Tops CM, Leeuwen-Cornelisse IS, Wijnen JT, van der Klift HM, Plug RJ, Griffioen G, Fodde R. Molecular analysis of the APC gene in 105 Dutch kindreds with familial adenomatous polyposis: 67 germline mutations identified by DGGE, PTT, and southern analysis. Hum Mutat 1997;9:7-16.

18 De Marco MF, Janssen-Heijnen ML, van der Heijden LH, Coebergh JW. Comorbidity and colorectal cancer according to subsite and stage: a population-based study. Eur J Cancer 2000;36:95-9.

19 Bulow S, Bjork J, Christensen IJ, Fausa O, Jarvinen H, Moesgaard F, Vasen HF. Duodenal adenomatosis in familial adenomatous polyposis. Gut 2004;53:381-6.

20 Soravia C, Berk T, Madlensky L, Mitri A, Cheng H, Gallinger S, Cohen Z, Bapat B. Genotype-phenotype correlations in attenuated adenomatous polyposis coli. Am J Hum Genet 1998;62:1290-301.
21 Le Page F, Randrianarison V, Marot D, Cabannes J, Perricaudet $M$, Feunteun J, Sarasin A. BRCA1 and BRCA2 are necessary for the transcriptioncoupled repair of the oxidative 8-oxoguanine lesion in human cells. Cancer Res 2000;60:5548-52.

22 Sieber OM, Howarth KM, Thirlwell $C$, Rowan A, Mandir N Goodlad RA Gilkar A, Spencer-Dene B, Stamp G, Johnson V, Silver A, Yang H, Miller JH, lyas $M$, Tomlinson IP. Myh deficiency enhances intestinal tumorigenesis in multiple intestinal neoplasia (ApcMin/+) mice. Cancer Res 2004;64:8876-81.

23 Venesio T, Molatore S, Cattaneo F, Arrigoni A, Risio M, Ranzani GN. High frequency of MYH gene mutations in a subset of patients with familial adenomatous polyposis. Gastroenterology 2004; 126:1681-5.

24 Enholm S, Hienonen T, Suomalainen A, Lipton L, Tomlinson I, Karja V, Eskelinen M, Mecklin JP, Karhu A, Jarvinen HJ, Aaltonen LA. Proportion and phenotype of MYH-associated colorectal neoplasia in a population-based series of finish colorectal cancer patients. Am J Pathol 2003; 163:827-32.

25 Fleischmann C, Peto J, Cheadle J, Shah B, Sampson J, Houlston RS. Comprehensive analysis of the contribution of germline $\mathrm{MYH}$ variation to early-onset colorectal cancer. Int J Cancer 2004; 109:554-8. 